\title{
Intra-annual tree growth responds to micrometeorological variability in the central Amazon
}

\author{
Saul Alfredo Antezana-Vera ${ }^{(1)}$, \\ Ricardo Antonio Marenco ${ }^{(2)}$
}

\section{Introduction}

The Amazon rainforest covers a large area (about $5.3 \times 10^{6} \mathrm{~km}^{2}$ ) and plays an important role in the global carbon and water cycle, storing about $86 \mathrm{Pg} \mathrm{C}$ in total biomass (Saatchi et al. 2007, Marengo et al. 2018). Even when an increase in atmospheric $\mathrm{CO}_{2}$ can enhance the ecosystem

(1) Instituto Nacional de Pesquisas da Amazônia - INPA, Botany Graduate Program, Avenida André Araújo, 2936, 69067-375 Manaus, AM (Brazil); (2) Instituto Nacional de Pesquisas da Amazônia - INPA, Coordination of Environmental Dynamic, Tree Ecophysiology Laboratory, 69067-375 Manaus, AM (Brazil)

\section{@ Ricardo Antonio Marenco (rmarenco@inpa.gov.br)}

Received: May 21, 2020 - Accepted: Apr 08, 2021

Citation: Antezana-Vera SA, Marenco RA (2021). Intra-annual tree growth responds to micrometeorological variability in the central Amazon. iForest 14: 242-249. - doi: 10.3832/ifor3532-014 [online 2021-05-21]

Communicated by: Rossella Guerrieri

Intra-annual distribution of precipitation in central Amazonia leads to a short mild dry season, which is associated with an increase in irradiance and temperature and a decline in relative humidity; however, the independent effect of each individual climatic variable on tree growth is still under investigation. The objective of this study was to determine how tree growth (inferred from radial stem increment) responds to monthly variations of micrometeorological variables in the central Amazon. During five years (2013-2017) we measured tree growth in 51 trees from nine species and, above the forest canopy, collected environmental data, such as photosynthetically active radiation (PAR), air temperature $(T)$, precipitation, air relative humidity $(\mathrm{RH})$, air vapor pressure deficit (VPD), reference evapotranspiration (ETo), and soil water content (SWC). We used principal component regression to evaluate the effect of micrometeorological variability on tree growth. Mean tree growth across species was responsive to variations in almost all the micrometeorological variables examined, with the exception of mean and minimum temperature, maximum $\mathrm{RH}$, and minimum VPD. Mean tree growth across species increased with increasing precipitation, $\mathrm{RH}_{\text {mean }}, \mathrm{RH}_{\min }$ and $\mathrm{SWC}$, while it decreased with increasing PAR, $T_{\max }$, and $\mathrm{ET}_{0}$. It was also shown that an increase in $\mathrm{VPD}_{\text {mean }}$ and $\mathrm{VPD}_{\max }$ has a negative effect on tree growth. These results contribute to improve our understanding of effect of climate variability on tree growth, and shed light on the potential effect of severe droughts in the central Amazon.

Keywords: Atmospheric Evaporative Demand, Tropical Rainforest, Wood Density

photosynthesis (Lloyd \& Farquhar 2008), the impact of droughts can alter the integrity of the rainforest ecosystem in the Amazon region (Marengo et al. 2018). Tree growth is defined as the gain in biomass and is often estimated by measuring the stem diameter increment over time (Silva et al. 2003 Wagner et al. 2012, Méndez 2018). It can be limited by several factors, including nutrient availability, irradiance, precipitation and soil water content. Variations in irradiance (Wagner et al. 2014, Rowland et al. 2014), precipitation (Méndez 2018, Yang et al. 2018), and leaf nutrient content (Mendes et al. 2013) have been reported to affect either photosynthesis or tree growth in the Amazon region. In central Amazonia the positive effect of precipitation on tree growth is less evident or not significant in the wettest years (Silva et al. 2003, Dias \& Marenco 2016), because the cloudiness associated with the rainy season, greatly reduces incoming radiation.

Actually, in the wettest part of the Amazon (north and central Amazon), it has been reported that ecosystem photosynthesis tends to increase in the dry season, following a slight increase in vapor pressure deficit (VPD - Green et al. 2020). Likewise, Rowland et al. (2014) also reported that at an eastern Amazonian forest with a strong rainfall pattern, carbon accumula- tion was greater in the dry season than in the wet season, in that case, accompanying an increase in solar radiation. The effect of temperature on tree growth is also still to be elucidated. For instance, Laurance et al. (2009) reported that in the central Amazon tree growth increased with an increase in maximum temperature $\left(T_{\max }\right)$, while the opposite was found by Méndez (2018).

In the central Amazon, evapotranspiration (ET) tends to increase in the dry season (Juárez et al. 2007, Hasler \& Avissar 2007, Costa et al. 2010, Antezana-Vera \& Marenco 2020). A rise in VPD and transpiration during the dry season can lead to a drop in stomatal conductance (and hence in photosynthesis), as stomatal conductance often decreases with increasing VPD (McDowell \& Allen 2015). While in southeastern Amazonia a sustained increase in VPD seems to be the trend of last three decades, in the north and central Amazon, a substantial increase in VPD has only been reported during prolonged dry seasons (Barkhordarian et al. 2019). Indeed, the increase in VPD observed during the drought of 2015 was associated with a drop in suninduced fluorescence, an indicator of photosynthesis over the whole Amazon region (Yang et al. 2018).

Although much research has been carried out to assess the effect of climatic parame- 
ters on tree growth in tropical rainforest (Wagner et al. 2014, Dias \& Marenco 2016, Méndez 2018), there is still no consensus on the relative importance of each individual climatic parameter on tree growth. In fact, as the climatic variables are correlated, the individual effects of climatic variables on tree growth or plant functioning are difficult to be demonstrated (Grossiord et al. 2020). Therefore, to evaluate the relative contribution of each climatic variable on tree growth, it is essential to remove the effect of collinearity. This is important, because in tropical rainforests the effect of micrometeorological variability on tree growth can be as low as 9\% of the total variance (Wagner et al. 2012). An accurate estimate of the effect of micrometeorological variability on tree growth is of paramount importance because of the great influence of the Amazon forest on the global carbon balance and water cycle. The main objective of this study was to determine how tree growth (as inferred from radial stem increment) responds to monthly variations of micrometeorological variables in the central Amazon. In this study we hypothesize that, in the central Amazon, mean tree growth positively responds to an increase in vapor pressure deficit (VPD), temperature and photosynthetically active radiation (PAR), and negatively to an increase in precipitation.

\section{Materials and methods}

\section{Study site}

The study was conducted at the Tropical Forest Experiment Station (ZF2 Reserve), located at a terra-firme rainforest plateau in central Amazonia, about $60 \mathrm{~km}$ north of Manaus ( $02^{\circ} 36^{\prime} 21^{\prime \prime} \mathrm{S}, 60^{\circ} 08^{\prime} 11^{\prime \prime} \mathrm{W}, \approx 120 \mathrm{~m}$ above sea level). In this area the leaf area index varies from 4.7 in dry season to 5.0 in the wet season (Mendes \& Marenco 2010) and tree density is high. In a tree inventory conducted in the central Amazon, Rankin-
De-Mérona et al. (1992) found a tree density $(>10 \mathrm{~cm}$ diameter at breast height DBH) of 636 trees per ha, canopy height was $35-40 \mathrm{~m}$ (most of trees with $<30 \mathrm{~cm}$ in diameter), while the mean stem length (height to the first branch) was $11.6 \mathrm{~m}$. In the region, tree species diversity is very high; for instance, at an experimental site ( $\mathrm{km} 30$ of Manaus), Prance et al. (1976) recorded 179 species of trees in one hectare $(\geq 15 \mathrm{~cm} \mathrm{DBH})$, while the production of new leaves tends to be more concentrated in the dry season (Alencar et al. 1979, Marenco et al. 2019).

The mean annual precipitation is 2420 $\mathrm{mm}$ (Dias \& Marenco 2016), with a mild dry season which extends from June to October, being July-September the driest months ( $\leq 100 \mathrm{~mm}$ per month, rainfall data for Manaus over the 1930-2010 period - INMET 2021); while the rainy season prolongs from November to May. At a nearby site $\left(\mathrm{K} 34-60^{\circ} 13^{\prime} \mathrm{W}, 02^{\circ} 36^{\prime} \mathrm{S}\right)$, the actual evapotranspiration (ET) is about $3.4 \mathrm{~mm}^{-1 a y}{ }^{-1}$ in the wet season and $3.7 \mathrm{~mm} \mathrm{day}^{-1}$ in the dry season (mean of $1300 \mathrm{~mm} \mathrm{yr}^{-1}$ ); VPD and surface conductance (a proxy of canopy conductance in dense forests) vary from $7.1 \mathrm{hPa}$ and $0.018 \mathrm{~m} \mathrm{~s}^{-1}\left(\sim 0.72 \mathrm{~mol} \mathrm{~m}^{-2} \mathrm{~s}^{-1}\right)$ in the dry season to $4.9 \mathrm{hPa}$ and $0.022 \mathrm{~m} \mathrm{~s}^{-1}$ $\left(\sim 0.89 \mathrm{~mol} \mathrm{~m}^{-2} \mathrm{~s}^{-1}\right)$ in the wet season (Costa et al. 2010). Mean temperature and RH are about $26{ }^{\circ} \mathrm{C}$ and $76 \%$, respectively (Antezana-Vera \& Marenco 2020), while net radiation is $130 \mathrm{~W} \mathrm{~m}^{-2}$ (wet season) and $140 \mathrm{~W}$ $\mathrm{m}^{-2}$ in the dry season, with a mean net radiation of 11.7 MJ day ${ }^{-1}$ (Costa et al. 2010). The soil type is an Oxisol (Yellow Latosol) of clay texture and low fertility. The soil water content (SWC) held at tension of -1.5 MPa (often called the permanent wilting point) is about $0.30 \mathrm{v} / \mathrm{v}$ (Ranzani 1980), and although soil water from the top layers supplies most of the transpirational demand, under prolonged drought roots can extract water from deep soil layers (> $4.8 \mathrm{~m}$ depth, Broedel et al. 2017).
Micrometeorological environment, plant material and tree growth

During the 2013-2017 period, air temperature $(T)$, PAR, $\mathrm{RH}$, and precipitation $(\mathrm{Pr})$ data were daily recorded above the forest canopy, at the top of a 40-m-tall observation tower ( $02^{\circ} 35^{\prime} 21^{\prime \prime} \mathrm{S}, 60^{\circ} 06^{\prime} 53^{\prime \prime} \mathrm{W}$ ). PAR was measured using a quantum sensor (Li-19oSA, Li-Cor, NE, USA), and air temperature and $\mathrm{RH}$ with a temperature-humidity sensor (Humitter 50y, Oy Vaisala, Finland) connected to a data logger (LI1400, Li-Cor, Lincoln, NE). Data were collected at 15 min (PAR) or 30 min intervals ( $T$ and $R H$ ). PAR data were integrated over time to obtain daily PAR values $\left(\mathrm{mol} \mathrm{m}^{-2}\right.$ $\mathrm{d}^{-1}$ ). Precipitation data were recorded using a rain gauge (Em5b, Decagon, WA, USA). We used RH (\%) and air temperature $\left(T,{ }^{\circ} \mathrm{C}\right)$ to compute vapor pressure deficit (VPD, in $\mathrm{hPa}$ ) as previously described (Marenco et al. 2014). VPD was obtained from $\mathrm{RH}$ and air temperature $(T)$ data, $\mathrm{VPD}_{\min }$ from $\mathrm{RH}_{\text {max }}$ and mean minimum $T\left(T_{\min }\right)$, while $V P D_{\max }$ was obtained from mean $\mathrm{RH}_{\min }$ and mean maximum $T\left(T_{\max }\right)$ data. Reference evapotranspiration $\left(\mathrm{ET}_{\mathrm{o}}\right.$ ) was calculated as: $\mathrm{ET}_{\mathrm{o}}=$ $0.0023\left(T_{\text {mean }}+17.8\right)\left(T_{\text {max }}-T_{\text {min }}\right)^{0.5} R_{\mathrm{a}}$, where $R_{a}$ is the extraterrestrial radiation (Allen et al. 1998). In addition, we also measured soil water content SWC (\%, v/v) at about twoweek intervals, by collecting undisturbed soil samples at $10-20 \mathrm{~cm}$ depth, which were oven-dried at $105^{\circ} \mathrm{C}$ as previously described (Marenco et al. 2014).

In this study we collected data from 51 trees of nine evergreen species; each of the selected species had at least four replications (Tab. 1). In these trees we measured stem diameter increment (an estimator of tree growth, TG) at breast height (DBH, $1.3 \mathrm{~m}$ above the ground) at monthly intervals during 60 months (2013-2017). TC was measured using stainless steel dendrometer bands installed at least two years before the beginning of the current experiment. We also measured wood density

Tab. 1 - Mean wood density (WD, \pm SE), mean monthly growth rates $(T G, \pm S E)$, tree height $( \pm S D)$ and mean diameter at breast height ( \pm SD) of trees. (Abbr): abbreviation; ( $n$ ): number of trees; (Ecol): Eschweilera collina (Lecythidaceae); (Garg): Geissospermum argenteum (Apocynaceae); (Ilau): Inga laurina (Fabaceae); (Lmic): Licania micrantha (Chrysobalanaceae); (Pmac): Pouteria macrophylla (Sapotaceae); (Pdec): Protium decandrum (Burseraceae); (Smic): Scleronema micranthum (Malvaceae); (Stom): Swartzia tomentifera (Fabaceae); (Tven): Tachigali venusta (Fabaceae). In WD and TG columns, means followed by a different letter are significantly different $(p \leq 0.01)$ after Tukey test.

\begin{tabular}{|c|c|c|c|c|c|c|c|}
\hline Species & Abbr & $\mathrm{n}$ & $\begin{array}{l}\text { Height } \\
\text { (m) }\end{array}$ & $\begin{array}{l}\text { Diameter } \\
(\mathrm{cm})\end{array}$ & $\begin{array}{l}\text { WD } \\
\left(\mathrm{g} \mathrm{cm}^{-3}\right)\end{array}$ & $\begin{array}{l}\text { TG } \\
\left(\mathrm{mm} \text { month }^{-1}\right)\end{array}$ & Some uses \\
\hline Eschweilera collina & Ecol & 7 & $22.25 \pm 3.5$ & $20.7 \pm 6.1$ & $0.79 \pm 0.01 \mathrm{bc}$ & $0.058 \pm 0.068^{b}$ & Timber potential \\
\hline Geissospermum argenteum & Garg & 6 & $27.1 \pm 5.3$ & $34.1 \pm 13.4$ & $0.80 \pm 0.01 b c$ & $0.099 \pm 0.074 a \mathrm{ab}$ & Pharmacological potential \\
\hline Inga laurina & Ilau & 5 & $21.2 \pm 4.1$ & $18.9 \pm 6.6$ & $0.73 \pm 0.02^{c d}$ & $0.132 \pm 0.08^{a b}$ & Shading tree in agroforestry \\
\hline Licania micrantha & Lmic & 4 & $23.9 \pm 3.8$ & $23.7 \pm 9.8$ & $0.79 \pm 0.02^{b c}$ & $0.258 \pm 0.09 a b$ & Timber potential \\
\hline Pouteria macrophylla & Pmac & 4 & $24.9 \pm 5.8$ & $28.3 \pm 14.9$ & $0.92 \pm 0.02^{a}$ & $0.110 \pm 0.09 a b$ & The tree produces edible fruits \\
\hline Protium decandrum & Pdec & 6 & $21.5 \pm 1.6$ & $18.6 \pm 2.6$ & $0.59 \pm 0.01^{\mathrm{e}}$ & $0.106 \pm 0.07 \mathrm{ab}$ & The tree produces essential oils \\
\hline Scleronema micranthum & Smic & 5 & $28.5 \pm 3.2$ & $36.8 \pm 10.4$ & $0.67 \pm 0.02^{c}$ & $0.243 \pm 0.08^{a b}$ & Timber industry \\
\hline Swartzia tomentifera & Stom & 6 & $23.4 \pm 4.9$ & $24.1 \pm 9.5$ & $0.82 \pm 0.01^{b}$ & $0.086 \pm 0.07^{\mathrm{ab}}$ & Timber potential \\
\hline Tachigali venusta & Tven & 8 & $25.2 \pm 6.5$ & $29.7 \pm 17.0$ & $0.54 \pm 0.01^{e}$ & $0.473 \pm 0.06^{a}$ & No information \\
\hline Mean or total & - & 51 & 24.2 & 26.1 & $0.74 \pm 0.04$ & $0.173 \pm 0.01$ & - \\
\hline
\end{tabular}


(WD, dry mass to fresh volume ratio) by extracting one core sample per tree ( 3 to 5 $\mathrm{cm}$ in length and $5.15 \mathrm{~mm}$ in diameter) with an increment borer (Haglöf, Sweden). The core sample was extracted at about $1.3 \mathrm{~m}$ from the ground and at random days during the experimental period. Tree height was estimated using a regression model developed for trees of the central Amazon (Nogueira et al. 2008).

\section{Statistical analyses}

To assess differences among species, the effects of months and years on TG, and the effect of interactions, we conducted a repeated-measures analysis of variance using the following hierarchical model (eqn. 1):

$$
\begin{aligned}
Y_{i j k l} & =\mu+\alpha_{i}+\beta_{j}+\gamma_{k} \\
& +(\alpha \beta)_{i j}+(\alpha \gamma)_{i k}+(\beta \gamma)_{j k} \\
& +(\alpha \beta)_{i j k}+\varepsilon_{i j k}
\end{aligned}
$$

where $Y_{\mathrm{ijkl}}$ is the observation that represents the growth of a tree; $\mu$ a constant; $\alpha_{i}$, $\beta_{\mathrm{j}}$, and $\gamma_{\mathrm{k}}$ represent the effect of $i$-th species, $j$-th years, and $k$-th months; $(\alpha \beta)_{i i}$, $(\alpha \gamma)_{\mathrm{ik},}(\beta \gamma)_{\mathrm{ik}}$, and $(\alpha \beta \gamma)_{\mathrm{ijk}}$ denote the effect of the interactions; and $\varepsilon_{\mathrm{ijk}}$ indicates the error term.

We used principal component regression (PCR - Montgomery et al. 2012) to evaluate the effect of monthly variations of micrometeorological variables on detrended tree growth $\left(T_{G C}\right)$. By performing PCR the collinearity among regressors was removed, and hence the variance inflation factor (VIF, a measure of collinearity between the predicting variables) became unity. The VIF is $1 /\left(1-R^{2}\right)$; thus, when the correlation $(R)$ among regressors in null $\left(R^{2}=0\right)$, VIF $=1.0$ (Montgomery et al. 2012). In the PCR analysis, we used $T_{C C}$ instead of raw tree growth data (TG), because a time-related trend in tree growth can affect PCR results (Monserud \& Marshall 2001). This step was accomplished by using a first-order autoregression (Montgomery et al. 2012). Prior to subjecting the $T_{\mathrm{CC}}$ to $\mathrm{PCR}$, the climatic data were standardized (observed value minus the mean divided by the standard deviation). In matrix notation, a standard multiple linear regression (MLR) model can be represented by eqn. 2 (Montgomery et al. 2012):

$$
\mathbf{Y}=\mathbf{X b}+\epsilon
$$

In eqn. 2, $\mathrm{Y}$ is the observation vector (dependent variable), $\mathbf{X}$ the matrix of regressors (also called design matrix), $\mathbf{b}$ the vector of coefficients, and $\boldsymbol{\epsilon}$ the vector of random error terms. Likewise, a PCR model can be represented by eqn. 3 , while the calculations required to compute the regression coefficients and test their significance are given in eqn. 4-15 (Montgomery et al. 2012):

$$
\mathbf{Y}=\mathbf{Z} \boldsymbol{\alpha}+\epsilon
$$

$$
\mathrm{Z}=\mathrm{XT}
$$

$$
\alpha=\mathbf{T}^{\prime} \mathbf{b}
$$

$$
T^{\prime} X^{\prime} X T=Z^{\prime} Z=\Lambda
$$

$$
\mathbf{Z}=\left[z_{1}, z_{2}, \ldots, z_{u}\right]
$$

In eqn. 3 , the columns of $\mathbf{Z}$ represent a new set of orthogonal scores (z-scores). In eqn. 4 , $T$ is a matrix whose columns represent eigenvectors (derived from $\mathbf{X}$ data), while in eqn. $5, \alpha$ represents a vector of regression coefficients. In eqn. $6, \Lambda$ denotes a diagonal matrix $(p \times p$, being $p$ is the number of regressors in matrix $X$ ) of the eigenvalues $\left(\lambda_{1}, \lambda_{2}, \ldots \lambda_{p}\right)$ of $X^{\prime} \mathbf{X}$. In eqn. 7 , the orthogonal $z$-scores $\left(z_{1}, z_{2}, \ldots, z_{u}\right)$ are often termed principal components. The estimator of $\hat{\alpha}$ and its variance-covariance are computed as shown in eqn. 8-9.

$$
\begin{aligned}
& \hat{\boldsymbol{\alpha}}=\left(\mathbf{Z}^{\prime} \mathbf{Z}\right)^{-1} \mathbf{Z}^{\prime} \mathbf{Y}=\boldsymbol{\Lambda}^{-1} \mathbf{Z}^{\prime} \mathbf{Y} \\
& \operatorname{var} \hat{\boldsymbol{\alpha}}=\sigma^{2}\left(\mathbf{Z}^{\prime} \mathbf{Z}\right)^{-1}=\sigma^{2} \Lambda^{-1}
\end{aligned}
$$

For standardized regressors (eqn. 10, eqn. 11):

$$
\mathbf{b}=\mathbf{T} \hat{\alpha}
$$

$$
\operatorname{var}(\mathbf{b})=\operatorname{var} \mathbf{T} \hat{\boldsymbol{\alpha}}=\mathbf{T} \Lambda^{-1} \mathbf{T}^{\prime} \sigma^{2}
$$

The standardized regressors $\left(b_{\mathrm{pc}}\right)$, the variance, and standard error of $b_{p c}(\mathrm{SE})$ are given by eqn. 12-14. In eqn. 12, the "pc" subscript indicates that the principal components corresponding to near-zero eigenvalues have been removed from the analysis; likewise, the " $u$ " in the second part of eqn. 12 is the number of principal components retained in the reduced PCR model (i.e., after discarding principal components associated with near-zero eigenvalues).

$$
\begin{aligned}
& \mathbf{b}_{p c}=\mathbf{T} \hat{\boldsymbol{\alpha}}_{p c}=\sum_{j=1}^{u} \frac{t_{j}{ }^{\prime} \mathbf{X}^{\prime} \mathbf{y} t_{j}}{\lambda_{j}} \\
& \operatorname{var}\left(\mathbf{b}_{j, p c}\right)=\sigma^{2} \sum_{j=1}^{u} \frac{t_{i m}^{2}}{\lambda_{m}} \\
& S E\left(\mathbf{b}_{j, p c}\right)=\sqrt{\frac{\mathbf{M S E}}{n-1} \sum_{m=1}^{u} \frac{t_{j m}^{2}}{\lambda_{m}}}
\end{aligned}
$$

The significance of $\mathbf{b}_{\mathrm{pc}}$ can be tested on individual coefficients by using the statistic $t_{n-k-1}$, where $k$ represents the number of principal components in the reduced model, as described in eqn. 15:

$$
t=\frac{\mathbf{b}_{j, b c}}{S E\left(\mathbf{b}_{j, p c}\right)}
$$

In eqn. 14, the MSE is obtained as the regression of $\mathrm{Y}$ on the u-principal components retained in the model, while $t_{j m}$ denotes the $j$-th element of the eigenvector $t_{m}(m=1, \ldots, u)$. As supplementary information, the bivariate Pearson's correlations between climate variables were also determined. Statistical analyses were carried out using Statistica ${ }^{\circledR}$ v. 7.0 (StatSoft, Inc., Tulsa, OK, USA).

\section{Results}

Micrometeorological variables and tree growth

During the study period $T_{\text {mean }}$ was $26.5^{\circ} \mathrm{C}$, $\mathrm{RH}_{\text {mean }} 78.9 \%$, and PAR $28.9 \mathrm{~mol} \mathrm{~m}^{-2} \mathrm{~d}^{-1}$, with variations in minimum and maximum values as described in Fig. 1. Mean SWC was $44.3 \%$ and mean values of VPD and $\mathrm{ET}_{\text {。 }}$ were $7.4 \mathrm{hPa}$ and $120.8 \mathrm{~mm}$ month ${ }^{\epsilon^{\prime 1}}$, respectively (Fig. 1). Although the mean precipitation of the 2013-2017 period was close to the historical mean $\left(2420 \mathrm{~mm} \mathrm{yr}^{-1}\right)$, it was irregularly distributed (Fig. 2), and as expected, the climatic variables were correlated (Tab. S1 in Supplementary material). Tree growth significantly differed among years $(p=0.025)$, species $(p=$ $0.003)$, and months ( $p<0.001$ - see ANOVA in Tab. S2), and within a year the trees grew more slowly in the dry season than in the wet season ( $0.117 \mathrm{vs} .0 .215 \mathrm{~mm} \mathrm{month}^{-1}$, respectively; $p<0.001$ - Fig. $3 A$ ).

The highest growth rates were recorded in Tachigali venusta ( $\left.0.473 \mathrm{~mm} \mathrm{month}^{-1}\right)$ and the lowest one in Eschweilera collina ( 0.058 $\mathrm{mm}$ month $^{-1}$ ), while the other seven species comprised a group with rather similar growth rates (Tab. 1). Tachigali venusta was the species with the lowest wood density (WD) and the highest growth rates, and across species tree growth was negatively correlated with wood density $(r=-0.42, p=$ 0.002 - Fig. 3B).

\section{Effect of micrometeorological \\ variability on tree growth}

In this section, we used the mean $T_{\mathrm{CC}}$ across species ( $\left.T_{\mathrm{cc}-\mathrm{mean}}\right)$ to describe the statistical procedure. The principal component analysis showed that the first four factors explained $92.9 \%$ of the total variance of the climatic data. The eigenvectors and eigenvalues associated with these four factors were used to compute the z-cores (eqn. 4) more closely associated with $T_{\mathrm{cc}}$. The regression of the first four $z$-cores $\left(z_{1}\right.$, $z_{2}, z_{3}$ and $z_{4}$ ) on the $T_{\text {cc-mean }}$ yielded four $\alpha$ coefficients (i.e., $\alpha_{1}=-0.012, p<0.001 ; \alpha_{2}=$ $0.012, p=0.08, \alpha_{3}=-0.020, p=0.02$, and $\alpha_{4}$ $=-0.003, p=0.68)$. Therefore, by observing the $p$ values of the $\alpha_{1-4}$-coefficients we were able to select the $z$-scores (i.e., $z_{1}$ and $z_{3}$ ) more closely related with $T_{\text {cc-mean }}$ (i.e., $\alpha_{1}=$ $-0.012, p<0.001$ and $\alpha_{3}=-0.020, p=0.02-$ Tab. S3 in Supplementary material). Thus, in the next step we only used $z_{1}$ and $z_{3}$ (PCR reduced model) to obtain the $P(R-b e t a$ coefficients $\left(\mathbf{b}_{\mathrm{pc}}\right)$ associated with each of the climatic variables, as described in eqn. 12. The regression of the $z_{1}$ and $z_{3}$-score on $T_{\text {cc-mean }}$ yielded the mean square error (MSE $=0.0050, R^{2}=0.264, p<0.001-$ Tab. S3), which was required to compute the standard error (eqn. 14) and for testing the significance of the beta coefficients $-b_{p c}$ (eqn. 15). By using this approach, the $\boldsymbol{b}_{\mathrm{pc}}$ described in Tab. 2 were obtained.

We found that most of the species were responsive to variations in SWC, $E T_{0}$, $V P D_{\text {max }}, \mathrm{RH}_{\text {min }}, \mathrm{RH}_{\text {mean }}$ and $T_{\text {max }}$, four species 


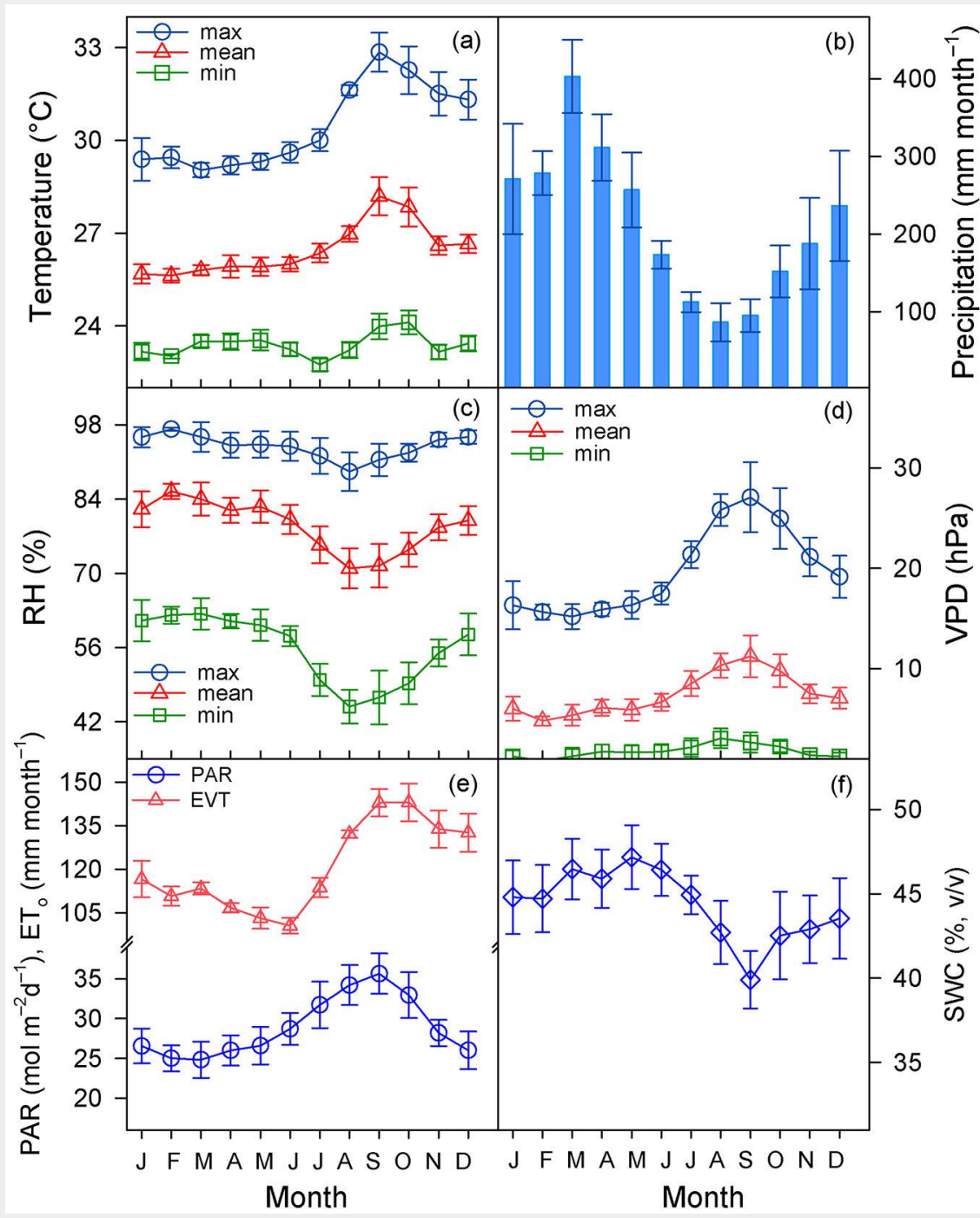

Fig. 1 - Monthly variation of air temperature (a), precipitation (b), relative humidity $(\mathrm{RH}$, c), and vapor pressure deficit (VPD, d), photosynthetically active radiation (PAR), and reference evapotranspiration $\left(\mathrm{ET}_{\mathrm{o}}, \mathrm{e}\right)$, and soil water content (SWC, f). Each symbol or bar represents the mean ( \pm standard error) of the indicated month over the years (20132017).

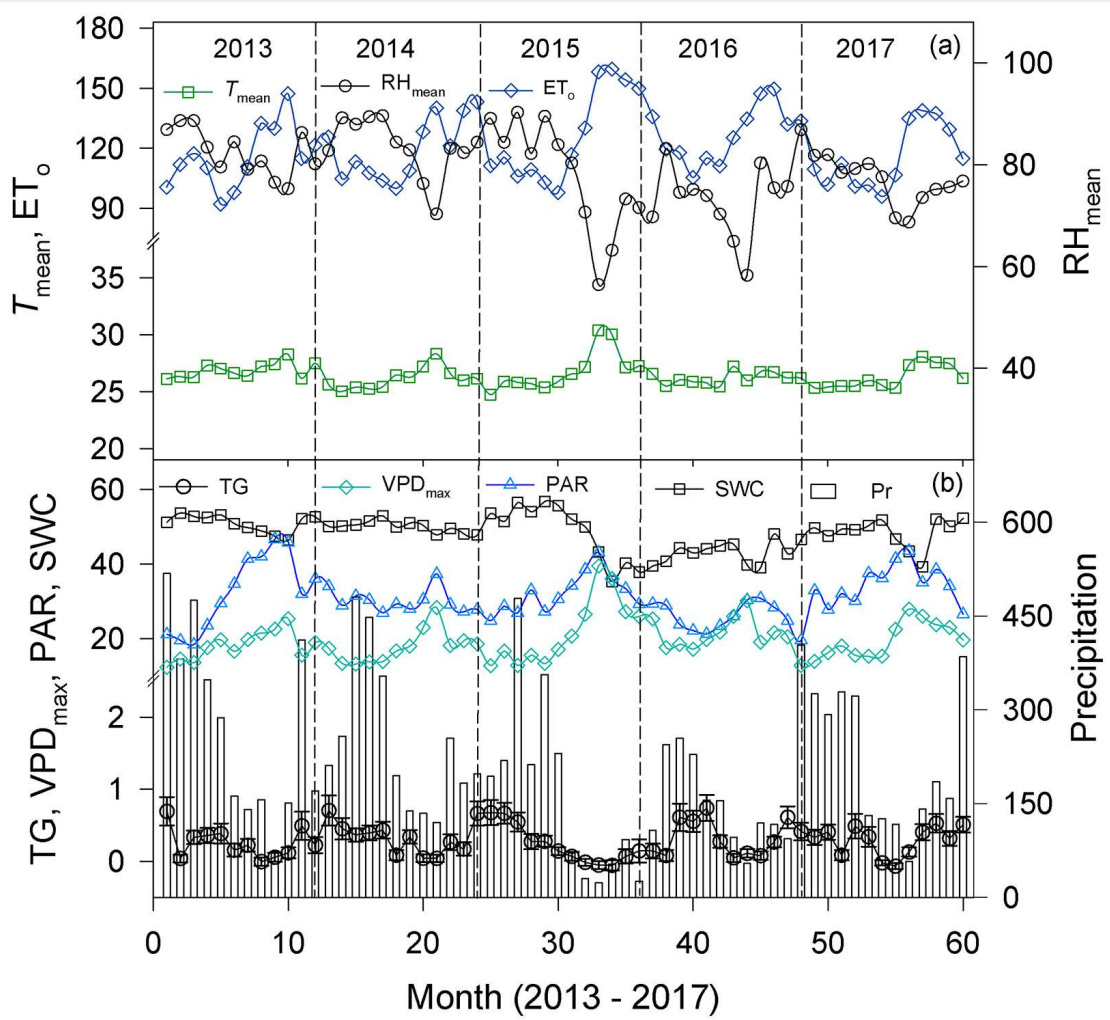

Fig. 2 - (a) Monthly variation of $T_{\text {mean }}\left({ }^{\circ} \mathrm{C}\right), \mathrm{ET}_{\mathrm{o}}$ (mm month ${ }^{-1}$ ), and $\mathrm{RH}_{\text {mean }}(\%)$, and (b) $\mathrm{VPD}_{\text {max }}$ (hPa), PAR ( $\left.\mathrm{mol} \mathrm{m}^{-2} \mathrm{~d}^{-1}\right)$, SWC (\%, v/v), precipitation (Pr, mm month ${ }^{-1}$, bar), and radial mean monthly growth rate (TG, $\mathrm{mm}$ month $^{-1}$ ) across species. Each symbol represents the mean value of the indicated month over the years (2013-2017). The vertical dashed line indicates the year. Other acronyms are as described in Fig. 1 and Tab. 2. 
Tab. 2 - Regression coefficients (Beta) obtained by Principal Component Regression (PCR) of the effect of climatic variables on detrended tree growth $\left(T_{\mathrm{CC}}\right)$ of the studied species. The $R^{2}$ (determination coefficient) of PCR is also shown. Abbreviations are shown in Tab. 1 and Fig. 1 . The standard error and $p$ value of coefficients are shown in Tab. S4 (Supplementary material). (*): $p<$ 0.05 .

\begin{tabular}{|c|c|c|c|c|c|c|c|c|c|c|}
\hline Species & Ecol & Garg & Ilau & Lmic & Pmac & Pdec & Smic & Stom & Tven & $T_{\text {GC-mean }}$ \\
\hline $\mathrm{R}^{2}$ & 0.08 & 0.06 & 0.18 & 0.12 & 0.17 & 0.1 & 0.1 & 0.22 & 0.22 & 0.26 \\
\hline PAR & $-0.0072^{*}$ & -0.0077 & $-0.0164^{*}$ & -0.0139 & -0.0106 & -0.0062 & -0.0158 & $0.0072^{*}$ & $-0.0352^{*}$ & $-0.0126^{*}$ \\
\hline $\operatorname{Pr}$ & 0.0003 & 0.0069 & $0.0149^{*}$ & 0.0134 & $0.0104^{*}$ & 0.0062 & 0.015 & 0.0006 & $0.0346^{*}$ & $0.0121^{*}$ \\
\hline$T_{\text {mean }}$ & -0.0036 & 0.0023 & 0.0044 & 0.0017 & 0.0009 & 0.0001 & 0.0026 & $-0.002^{*}$ & 0.0027 & 0.0016 \\
\hline$T_{\min }$ & $-0.0058^{*}$ & 0.008 & $0.0164^{*}$ & 0.012 & 0.0088 & 0.0047 & 0.0143 & $0.0031^{*}$ & 0.029 & 0.0109 \\
\hline $\mathrm{T}_{\max }$ & 0.0019 & -0.0013 & $-0.0031^{*}$ & $-0.0044^{*}$ & $-0.0037^{*}$ & $-0.0025^{*}$ & $-0.0044^{*}$ & $-0.0104^{*}$ & $-0.0072^{*}$ & $-0.0039^{*}$ \\
\hline $\mathrm{RH}_{\text {mean }}$ & 0.0001 & 0.0016 & $0.0039^{*}$ & $0.0052^{*}$ & $0.0043^{*}$ & $0.0029^{*}$ & $0.0052^{*}$ & -0.0016 & $0.0003^{*}$ & $0.0046^{*}$ \\
\hline $\mathrm{RH}_{\min }$ & 0.0021 & 0.0023 & $0.0053^{*}$ & $0.0063^{*}$ & $0.0051^{*}$ & $0.0033^{*}$ & $0.0065^{*}$ & -0.0028 & $-0.0036^{*}$ & $0.0056^{*}$ \\
\hline $\mathrm{RH}_{\max }$ & -0.0028 & -0.0016 & -0.0029 & -0.0006 & -0.0001 & 0.0004 & -0.0013 & -0.0009 & 0.0001 & -0.0006 \\
\hline$V P D_{\text {mean }}$ & -0.0009 & -0.0007 & -0.002 & -0.0038 & $-0.0033^{*}$ & -0.0023 & -0.0036 & 0.001 & $-0.0111^{*}$ & $-0.0034^{*}$ \\
\hline$V P D_{\min }$ & 0.0024 & 0.0021 & 0.0039 & 0.0013 & 0.0006 & -0.0001 & 0.0022 & 0.0009 & 0.0018 & 0.0012 \\
\hline $\mathrm{VPD}_{\max }$ & $-0.0011^{*}$ & -0.0016 & $-0.0039^{*}$ & $-0.0052^{*}$ & $-0.0044^{*}$ & $-0.003^{*}$ & $-0.0053^{*}$ & -0.0015 & $-0.0147^{*}$ & $-0.0047^{*}$ \\
\hline SWC & -0.0058 & 0.0017 & $0.0039^{*}$ & $0.0047^{*}$ & $0.0038^{*}$ & $0.0025^{*}$ & $0.0048^{*}$ & $0.0105^{*}$ & $0.0129^{*}$ & $0.0042^{*}$ \\
\hline ETo & 0.0036 & -0.0022 & $-0.005^{*}$ & $-0.0057^{*}$ & $-0.0046^{*}$ & $-0.003^{*}$ & $-0.006^{*}$ & $-0.0133^{*}$ & $-0.0153^{*}$ & $-0.0051^{*}$ \\
\hline
\end{tabular}

responded to variations in PAR and three species to changes in precipitation, while only two species responded to variations in $V P D_{\text {mean }}($ Tab. 2). It was also found that three species were responsive to variations in $T_{\min }$, while only Swartzia tomentifera was affected by variation in $T_{\text {mean }}$, whereas none of the species responded to variations in either $\mathrm{VPD}_{\min }$ or $\mathrm{RH}_{\max }$ (Tab. 2). The mean tree growth across species ( $T_{\text {CC-mean }}$ ) was responsive to variations in almost all micrometeorological variables investigated, the exceptions were $T_{\text {min }}, T_{\text {mean }}, \mathrm{RH}_{\text {max }}$ and $\mathrm{VPD}_{\text {min }}$, and together micrometeorological variability accounted for $26.4 \%$ of total variation in $T_{\text {cC-mean }}$ (Tab. S3 in Supplementary material). The $T_{\text {cc-mean }}$ as a function of standardized climatic variables can be represented by eqn. 16, whose coefficients are described in Tab. 2.

$$
\begin{aligned}
T_{G C-\text { mean }} & =-0.0126 P A R+0.0121 P r \\
& +0.0016 T_{\text {mean }}+0.0109 T_{\text {min }} \\
& -0.0039 T_{\text {max }}+0.0046 R H_{\text {mean }} \\
& +0.0056 R H_{\text {min }}-0.0006 R H_{\text {max }} \\
& -0.0034 V P D_{\text {mean }}+0.0012 V P D_{\text {min }} \\
& -0.0047 V P D_{\text {max }}+0.0042 S W C \\
& -0.0051 E T_{o}
\end{aligned}
$$

Because climatic variables were affected by seasonality, the variables that increased during the dry season, such as PAR, $T_{\max }$, $V P D_{\text {mean }}$, and $V P D_{\max }$ (Fig. 1) negatively affected tree growth. For instance, across species the reduction in tree growth in the dry season vs wet season (Fig. 3a) occurred simultaneously with a decrease (dry season vs. wet season) in precipitation (123.9 mm month $^{-1}$ vs. $277.9 \mathrm{~mm}$ month $^{-1}$ - Fig. 1) in combination with a rise in $T_{\max }(31.3$ Vs. 29.9 ${ }^{\circ} \mathrm{C}$ ), PAR (32.6 vs. $\left.26.2 \mathrm{~mol} \mathrm{~m}^{-2} \mathrm{~d}^{-1}\right), V_{\text {PDean }}$ (9.3 vs. $6.1 \mathrm{hPa}$ ), and $V \mathrm{PD}_{\max }(23.3$ vs. 17.1 $\mathrm{hPa})$.
Response of individual species to micrometeorological variability

On the responsiveness of individual species to micrometeorological variability, we found that Inga laurina and Tachigali venusta were the most responsive species, as they were affected by the variation of nine climatic variables ( $p \leq 0.05-$ Tab. 2$)$. Protium decandrum, Pouteria macrophylla, Scleronema micranthum, Licania micrantha and Swartzia tomentifera responded to variations in 6-8 micrometeorological variables, and hence, they constituted a second group, while the other two species (Eschweilera collina and Geissospermum argenteum, a third group) were less responsive to variations in the measured climatic variables. In fact, G. argenteum was only barely responsive to variation in precipitation, $\mathrm{RH}_{\min }$, SWC and $\mathrm{ET}_{0}(p<0.085)$. In comparison with the species that grew more slowly, there was a slight trend for species with faster growth rates $(\mathrm{mm}$ month $^{-1}$ ) to be more responsive to micrometeorological variability, e.g., T. venusta (0.473) and I. laurina (0.132) were more responsive to climatic variability than E. collina (0.058) or G. argenteum (0.099).

The majority of species responded to microclimatic variability in the same way, the exception were $S$. tomentifera, which positively responded to variations in PAR, and E. collina, which was negatively affected by an increase in $T_{\min }$. On average, PAR, $T_{\max }$,

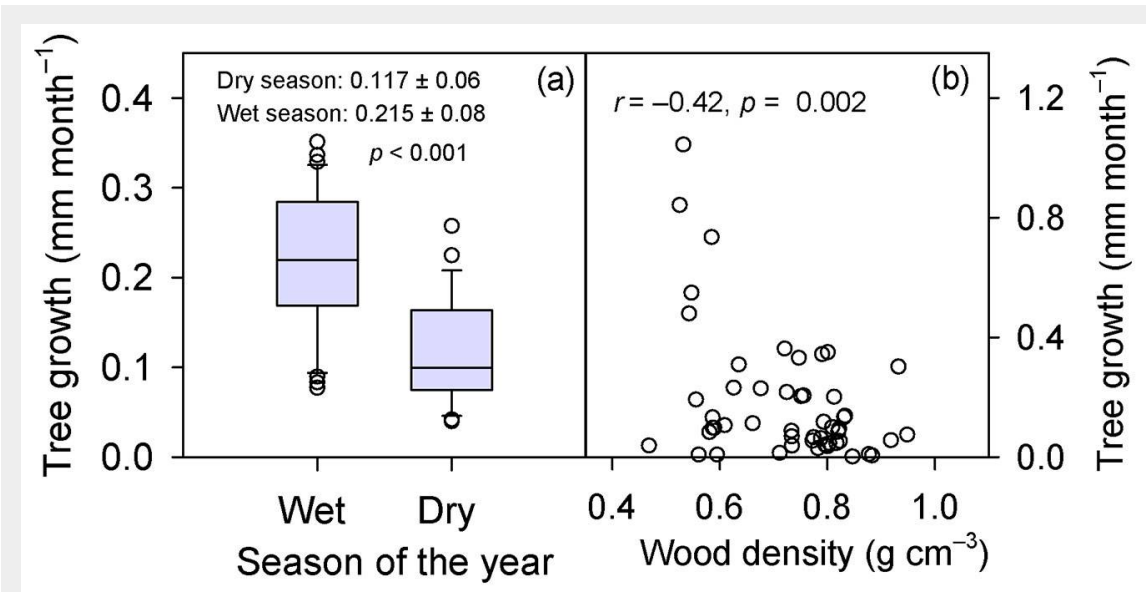

Fig. 3 - (a) Radial mean monthly growth rates (TG, raw data) across species ( 51 trees) recorded in the wet seasons (November-May) and dry seasons (June-October) throughout the experimental period (2013-2017). (b) The relationship between mean growth rate (TG) per tree and wood density, WD. In panel (a), the boundaries of the box indicate the $25^{\text {th }}$ and $75^{\text {th }}$ percentile, and the solid line within the box denotes the median; the mean value ( $\mathrm{mm} \mathrm{month}^{-1}$ ) within a season is also shown. In panel (b), each symbol corresponds to the mean growth rates of one tree over the five years (mean of 60 months), while WD represents the value of one sample per tree. 
$V P D_{\text {mean }}, V P D_{\max }$ and $\mathrm{ET}_{\mathrm{o}}$ had a negative effect on $T_{\mathrm{CC} \text {-mean }}$ (negative beta values in Tab. 2), while the effect of SWC, precipitation, $\mathrm{RH}_{\text {min }}$ and $\mathrm{RH}_{\text {mean }}$ was positive. Swartzia tomentifera responded to variation in $T_{\text {mean }}$ but the combined effects over species was too small to have a significant effect on $T_{\text {cc-mean. }}$ Although three species responded to variations in $T_{\min }$, the overall effect of $T_{\min }$ on $T_{\text {cc-mean }}$ was insignificant. This occurred because while I. laurina and S. tomentifera responded positively to $T_{\min }$, the opposite effect was observed in E. collina (Tab. 2).

\section{Discussion}

On average, tree growth was responsive to variations in nine out of the 13 micrometeorological variables studied, and we found that PCR explained $26.4 \%$ of the total variance. When the effect of climate variability on tree growth is under evaluation, a $R^{2}$ value of 0.26 is not unexpected, as many factors can affect tree growth (Bowman et al. 2013). For instance, Wagner et al. (2012) found that only $9 \%$ of the variation in tree growth can be ascribed to seasonal climate variability. Because climatic parameters were greatly influenced by micrometeorological seasonality, climatic variables that increased during the dry season negatively affected tree growth. For instance, taking the wet season as the base line, the reduction in tree growth (45.6\%) in the dry season occurred in parallel with a decrease in precipitation (55.4\%) and $\mathrm{RH}_{\min }$ $(17.1 \%)$, and with a rise in PAR (24.7\%), $V P D_{\text {mean }}(52.5 \%)$ and $V P D_{\text {max }}(36.5 \%)$. The decline in tree growth in the dry season is in agreement with the results reported by Wagner et al. (2014) for the central Amazon. Méndez (2018) also found a decline in tree growth during the drought of 20152016 in the central Amazon $\left(02^{\circ} 35^{\prime} \mathrm{S}, 60^{\circ}\right.$ $\left.12^{\prime} \mathrm{W}\right)$. Likewise, by using sun induced florescence, Lee et al. (2013) and Yang et al. (2018) found that leaf fluorescence (an estimator of photosynthesis) decreased during the dry season in the Amazon region, which ultimately can lead to a decline in biomass accumulation.

It has been reported that several climatic parameters, such as solar radiation, VPD and ET increase in the dry season. However, because the increase in VPD and ET during the dry season (Costa et al. 2010) occurs simultaneously with a decrease in precipitation (Antezana-Vera \& Marenco 2020) and SWC (Broedel et al. 2017), it is difficult to separate their respective contributions on tree growth by using standard multiple regression.

Even though reduced precipitation is one of the major climatic parameters associated with the dry season, our results clearly show that the increase in VPD (mean and maximum) and $\mathrm{ET}_{\mathrm{o}}$ have a significant effect on tree growth, which cannot be statistically ascribed to the influence of other climatic parameters, as the contribution of collinearity was removed. At same time, it is also shown that, irrespective of the di- rect influence of temperature on VPD, $T_{\max }$ by itself seems to have an effect on tree growth that cannot be attributed to the effect of VPD. This is important because it shows that when highly correlated variables are under investigation, as it often occurs with climatic variables, disregarding collinearity between variables can lead to imprecise results. In this work we hypothesized that mean tree growth positively responds to an increase in VPD, temperature and PAR, and negatively to an increase in precipitation, which was not supported by data, as across species a rise in PAR, $T_{\max }$, $V P D_{\text {max }}$ and $V P D_{\text {mean }}$ had a negative effect on tree growth across species, while an increase in precipitation and SWC had a positive effect.

Studies that aim to assess the effect of the dry season on tree growth in the Amazon have led to different conclusions, perhaps because the impact of drought on tree growth depends on the length of the dry season. For example, Silva et al. (2003) and Dias \& Marenco (2016) did not find a negative effect of the dry season on tree growth, whereas Wagner et al. (2014) reported that tree growth decreases in the dry season. In this study we found that the decrease in tree growth was essentially associated with an increase in PAR, $T_{\max }$ and $V P D_{\max }$, and with decline in precipitation and SWC.

A negative effect of PAR on tree growth is in contrast with the results reported by Rowland et al. (2014) who concluded that tree growth increased in the dry season when irradiance is more intense. The discrepancy can be ascribed to the length of the dry season, as it has been reported that root water uptake can be enhanced during drought (Markewitz et al. 2010, Broedel et al. 2017), which can help to withstand the effect of water stress in mild dry seasons.

It has been postulated that in the Amazon, precipitation can limit ecosystem photosynthesis up to about $2000 \mathrm{~mm} \mathrm{yr}^{-1}$, and that above this threshold solar radiation can be the limiting factor of photosynthesis (Ahlström et al. 2017). In this study, the trees grew more slowly with a reduction in precipitation and SWC, irrespective of an increase in PAR with decreasing precipitation, which shows that the distribution of precipitation within a year is of paramount importance for the effect of PAR on tree growth. We have shown that a decline in $V P D_{\text {max }}$ (also VPD $D_{\text {mean }}$ ) was associated with an increase in tree growth (Fig. 2, Tab. 2), and that VPD increased in the dry season (Fig. 1). It is known that stomatal conductance (and hence photosynthesis) is a function of VPD, being the most common response a decline in stomatal conductance with increasing VPD (Jones 1998, McDowell \& Allen 2015). Thus, it is plausible to infer that the effect of VPD ${ }_{\text {mean }}$ and VPD $D_{\max }$ on tree growth occurs via its effect on stomatal conductance. This is consistent with the findings of Lee et al. (2013) and Yang et al. (2018) who reported a decline in sun induced fluorescence in the dry season, which occurred in parallel with an increase in VPD.

We found a negative effect of $T_{\max }$ on tree growth, whereas over a wide range of tropical forest sites Wagner et al. (2014) reported that $T_{\max }$ has no significant effect on tree growth, and concluded that temperature variations are of secondary importance for tropical tree growth. This suggests that in comparison with other major drivers of tree growth, such as precipitation and solar radiation (Wagner et al. 2014, Méndez 2018), the effect of temperature is more difficult to detect. In tropical rainforests, the optimum temperature for photosynthesis is about $29{ }^{\circ} \mathrm{C}$ (Liu 2020), with decreasing photosynthetic rates at higher temperatures. Beside the indirect effect of temperature and relative humidity on photosynthesis ( $v i a$ its effect of VPD), an increase in temperature has also a direct effect on transpiration via the effect of temperature on water viscosity (Darcy's Law), and cuticular transpiration (Kerstiens 2006). Similarly, RH has also a direct effect on transpiration, as it may affect the hydration of cuticle components (Kerstiens 2006). An increase in $T_{\max }$ may have also a direct effect on tree growth via the effect of temperature on leaf respiration, isoprene emission and photorespiration (Sharkey \& Yeh 2001, Slot \& Winter 2016). As most of the species negatively responded to a decrease in SWC (the exception was $G$. argenteum; E. collina was barely responsive, $p=0.06$ ), it can be inferred that even when root water uptake can be enhanced under drought (Markewitz et al. 2010, Broedel et al. 2017), the increased water absorption during the dry season did not keep pace with the transpirational demand, which ultimately resulted in a reduction in tree growth.

One of the difficulties in assessing the in dividual effect of climatic variability on tree growth is to remove the effect of collinearity between the climatic drivers. By using PCR we show that the mean tree growth was responsive not only variation in precipitation, temperature $\left(T_{\max }\right)$, and PAR, but also to variation in relative humidity $\left(\mathrm{RH}_{\text {mean }}\right.$ and $\mathrm{RH}_{\min }$ ) and vapor pressure deficit $\left(V P D_{\text {mean }}\right.$ and $\left.V P D_{\text {max }}\right)$. This result is important because due to global warming (temperature is increasing about $0.16{ }^{\circ} \mathrm{C}$ per decade over the Amazon region), the rainfall pattern in the Amazon is changing, ranging from lower rainfall intensity (longer dry seasons) in eastern and southern Amazonia to higher rainfall intensity in the northern Amazon (Marengo et al. 2018). It has also been reported an increase in vapor pressure deficit, from a steady increase in southern Amazon (over last three decades) to episodic increases during drought events in the northwest of the Amazon region (Barkhordarian et al. 2019), when a decline in photosynthesis can occur (Yang et al. 2018). Therefore, an increase in 
VPD often leads to an increase in transpiration, which associated with a decline in precipitation can lead to severe water deficit and thereby to decline in photosynthesis except in the wettest part of the Amazon where a mild increase in VPD can enhance photosynthesis (Green et al. 2020). Moreover, under severe drought, high VPD can greatly reduce hydraulic conductivity, which can eventually affect the survival of trees (McDowell \& Allen 2015, Barkhordarian et al. 2019). Thus, if the dry season becomes longer and dryer, as predicted by models (Marengo et al. 2018), it may be expected that trees currently more sensitive to droughts will be the more affected by climate changes. These results contribute to improve our understanding of the ecophysiology of Amazonian trees and provide further information regarding the potential effects of increased drought in the Amazon region.

\section{Conclusions}

In this study we assessed the effect of several climatic parameters on tree growth, and we were able to remove the effect of collinearity among climatic variables by using principal component regression. On average, tree growth increased with increasing precipitation, $\mathrm{SWC}, \mathrm{RH}_{\min }$, and $\mathrm{RH}_{\text {mean }}$, while it decreased with increasing PAR, $T_{\max }$, and $\mathrm{VPD}_{\max }$ and $\mathrm{ET}_{\mathrm{o}}$, which conflicts with our working hypothesis. Thus, it seems plausible to conclude that the decline in tree growth that occurs during the dry season could reflect a decrease in the capacity of the tree to extract water from deeper soil layers to meet the increased transpirational demand during the dry season. A contribution of this study is to clearly demonstrate the effect of variations in $\mathrm{VPD}_{\text {mean }}$ and $\mathrm{VPD}_{\max }$ on tree growth of Amazonian trees. These results enhance our understanding of the ecophysiology of Amazonian trees and provide insights into the potential effects of severe droughts foreseen by climate models for the Amazon region.

\section{Acknowledgments}

We acknowledge the Ministry of Science, Technology and Innovations - National Institute for Research in the Amazon (MCTIINPA), the Foundation for Research Support of the State of Amazonas (FAPEAM), Coordination for the Improvement of Higher Education Personnel (CAPES code 0001) and the National Council for Scientific and Technological Development CNPq (303907/2018-5). We greatly appreciate the reviewers for their valuable comments, which greatly improved the quality of the manuscript.

\section{Abbreviations}

$\mathrm{DBH}$ : tree diameter at breast height; $\mathrm{ET}_{\mathrm{o}}$ : reference evapotranspiration; ET: evapotranspiration (actual); TG: tree growth (inferred from radial stem increment); $T_{\mathrm{cc} \text {-mean: }}$ : mean of detrended TG across species; PAR: photosynthetically active radiation; PCR: principal component regression; Pr: precipitation; $R^{2}$ : square of correlation (determination coefficient); $\mathrm{RH}$ : relative humidity; $\mathrm{RH}_{\text {max }}$ : mean maximum $\mathrm{RH} ; \mathrm{RH}_{\text {min }}$ : mean minimum $\mathrm{RH}$; $\mathrm{RH}_{\text {mean }}$ : mean $\mathrm{RH}$; SWC: soil water content; $T$ : air temperature; $T_{\text {max }}$ : mean maximum $T$; $T_{\text {min }}$ : mean minimum $T$; $T_{\text {mean }}$ : mean T; VPD: vapor pressure deficit; $V D_{\text {max }}$ : mean maximum VPD; $V_{P D_{\text {min }}}$ : mean minimum VPD; VPD mean: VPD mean. VIF: variance inflation factor; WD: wood density.

Species: Ecol: Eschweilera collina; Garg: Geissospermum argenteum; llau: Inga laurina; Lmic: Licania micrantha; Pdec: Protium decandrum; Pmac: Pouteria macrophylla; Smic: Scleronema micranthum; Stom: Swartzia tomentifera; Tven: Tachigali venusta.

\section{Conflict of Interest}

The authors declare that they have no conflict of interest.

\section{Author contributions}

SAAV collected data and conducted statistical analysis; RAM secured funding, collaborate in the analysis of data, supervised the experimental work, and wrote the article with contributions of the first author.

\section{References}

Ahlström A, Canadell JG, Schurgers G, Wu M, Berry JA, Guan K, Jackson RB (2017). Hydrologic resilience and Amazon productivity. Nature Communications 8: 1-9. - doi: 10.1038/s4146 7-016-0009-6

Alencar JD, Almeida RA, Fernandes NP (1979). Fenologia de espécies florestais em floresta tropical úmida de terra firme na Amazônia Central [Phenology of forest species in a tropical rainforest of Central Amazonia]. Acta Amazonica 9: 163-199 [in Portuguese] - doi: 10.1590/180 9-43921979091163

Allen RG, Pereira LS, Raes D, Smith M (1998). Crop evapotranspiration: guidelines for computing crop water requirements. Paper no. 56, United Nations FAO, Irrigation and Drainage, NY, USA. [online] URL: http://www.fao.org/do crep/Xo490E/Xo490Eoo.htm

Antezana-Vera SA, Marenco RA (2020). Sap flow rates of Minquartia guianensis in central Amazonia during the prolonged dry season of 20152016. Journal of Forestry Research [in press]. doi: 10.1007/s11676-020-01193-9

Barkhordarian A, Saatchi SS, Behrangi A, Loikith PC, Mechoso CR (2019). A recent systematic increase in vapor pressure deficit over tropical South America. Scientific Reports 9: 15331. - doi: 10.1038/s41598-019-51857-8

Bowman DM, Brienen RJ, Gloor E, Phillips OL, Prior LD (2013). Detecting trends in tree growth: not so simple. Trends in Plant Science 18: 11-17. - doi: 10.1016/j.tplants.2012.08.005

Broedel E, Tomasella J, Cndido LA, Von Randow $C$ (2017). Deep soil water dynamics in an undisturbed primary forest in central Amazonia: differences between normal years and the 2005 drought. Hydrological Processes 31: 1749-1759. doi: 10.1002/hyp.11143
Costa MH, Biajoli MC, Sanches L, Malhado ACM, Hutyra LR, Da Rocha HR, Aguiar RG, De Araújo AC (2010). Atmospheric versus vegetation controls of Amazonian tropical rain forest evapotranspiration: are the wet and seasonally dry rain forests any different? Journal of Geophysical Research 115 (G4): 248. - doi: 10.1029/2009J Go01179

Dias DP, Marenco RA (2016). Tree growth, wood and bark water content of 28 Amazonian tree species in response to variations in rainfall and wood density. iForest - Biogeosciences and Forestry 9: 445-451. - doi: 10.3832/ifor1676-008

Green JK, Berry J, Ciais P, Zhang Y, Gentine P (2020). Amazon rainforest photosynthesis increases in response to atmospheric dryness. Science Advances 6: eabb7232. - doi: 10.1126/sci adv.abb7232

Grossiord C, Buckley TN, Cernusak LA, Novick KA, Poulter B, Siegwolf RT, Sperry JS, McDowell NG (2020). Plant responses to rising vapor pressure deficit. New Phytologist 226: 15501566. - doi: 10.1111/nph.16485

Hasler N, Avissar R (2007). What controls evapotranspiration in the Amazon Basin? Journal of Hydrometeorology 8: 380-395. - doi: 10.1175/JH M587.1

INMET (2021). Graficos climatologicos [Weather charts]. Web site. [online] URL: http://clima.in met.gov.br/GraficosClimatologicos/DF/83377

Jones HG (1998). Stomatal control of photosynthesis and transpiration. Journal of Experimental Botany 49: 387-398. - doi: 10.1093/jxb/49.Sp ecial_Issue.387

Juárez RIN, Hodnett MG, Fu R, Goulden ML, Von Randow C (2007). Control of dry season evapotranspiration over the Amazonian forest as inferred from observations at a southern Amazon forest site. Journal of Climate 20: 28272839. - doi: 10.1175/JCLI4184.1

Kerstiens G (2006). Water transport in plant cuticles: an update. Journal of Experimental Botany 57: 2493-249. - doi: 10.1093/jxb/erlo17

Laurance SG, Laurance WF, Nascimento HE, Andrade A, Fearnside PM, Rebello ER, Condit R (2009). Long-term variation in Amazon forest dynamics. Journal of Vegetation Science 20: 323-333. - doi: 10.1111/j.1654-1103.2009.01044.x Lee J-E, Frankenberg C, Van Der Tol C, Berry JA, Guanter L, Boyce CK, Fisher JB, Morrow E, Worden JR, Asefi S, Badgley G, Saatchi S (2013). Forest productivity and water stress in Amazonia: observations from GOSAT chlorophyll fluorescence. Proceedings of the Royal Society B: Biological Sciences 280 (1761): 20130171. - doi: 10.1098/rspb.2013.0171

Liu Y (2020). Optimum temperature for photosynthesis: from leaf to ecosystem scale. Science Bulletin 65: 601-604. - doi: 10.1016/j.scib. 2020.01.006

Lloyd J, Farquhar GD (2008). Effects of rising temperatures and $\left[\mathrm{CO}_{2}\right]$ on the physiology of tropical forest trees. Philosophical Transactions of the Royal Society B: Biological Sciences 363: 1811-1817. - doi: 10.1098/rstb.2007.0032

Marenco RA, Nascimento HCS, Magalhães NDS (2014). Stomatal conductance in Amazonian tree saplings in response to variations in the physical environment. Photosynthetica 52: 493 500. - doi: 10.1007/s11099-014-0056-3

Marenco RA, Sousa FD, Oliveira MF (2019). Leaf 
phenology, growth and photosynthesis in Pseudobombax munguba (Malvaceae). Revista Ceres 66: 1-10. - doi: 10.1590/0034-730x2019660100 01

Marengo JA, Souza CM, Thonicke K, Burton C, Halladay K, Betts RA, Alves LM, Soares WR (2018). Changes in climate and land use over the Amazon region: current and future variability and trends. Frontiers in Earth Science 6: 228. - doi: 10.3389/feart.2018.00228

Markewitz D, Devine S, Davidson EA, Brando P, Nepstad DC (2010). Soil moisture depletion under simulated drought in the Amazon: impacts on deep root uptake. New Phytologist 187: 592607. - doi: 10.1111/j.1469-8137.2010.03391.x

McDowell N, Allen C (2015). Darcy's law predicts widespread forest mortality under climate warming. Nature Climate Change 5: 669-672. doi: 10.1038/nclimate2641

Mendes KR, Marenco RA, Magalhães NDS (2013). Growth and photosynthetic use efficiency of nitrogen and phosphorus in saplings of Amazonian tree species. Revista Arvore 37: 707-716. - doi: 10.1590/S0100-676220130004000 14

Mendes KR, Marenco RA (2010). Leaf traits and gas exchange in saplings of native tree species in the Central Amazon. Scientia Agricola 67: 624-632. - doi: 10.1590/S0103-901620100006000 02

Méndez CR (2018). Influência do El Niño 20152016 no incremento diamétrico das árvores da Amazônia Central [Influence of El Niño 20152016 in the diametric increment of the trees of the central Amazon]. MS thesis, Instituto Nacional de Pesquisas da Amazônia, Manaus, Brazil, pp. 71. [in Portuguese]

Monserud RA, Marshall JD (2001). Time-series analysis of $\delta^{13} \mathrm{C}$ from tree rings. I. Time trends and autocorrelation. Tree Physiology 21: 1087102. - doi: 10.1093/treephys/21.15.1087

Montgomery DC, Peck EA, Vining GG (2012). Principal component regression. In: "Introduction to Linear Regression Analysis". John Wiley and Sons, Hoboken, NJ, USA, pp. 313-319.

Nogueira EM, Nelson BW, Fearnside PM, França $M B$, De Oliveira AC (2008). Tree height in Brazil's "arc of deforestation": shorter trees in south and southwest Amazonia imply lower biomass. Forest Ecology and Management 255:
2963-2972. - doi: 10.1016/j.foreco.2008.02.002 Prance GT, Rodrigues WA, Silva MF (1976). Inventario florestal de um hectare de mata de terra firme $\mathrm{km} 30$ de Estrada Manaus-Itacoatiara [Forest inventory of one hectare of terra firma forest at $\mathrm{km} 30$ on the Manaus-Itacoatiara's road]. Acta Amazonica 6: 9-35 [in Portuguese] - doi: 10.1590/1809-43921976061009

Rankin-De-Mérona JM, Prance GT, Hutchings RW, Silva MF, Rodrigues WA, Uehling ME (1992). Preliminary results of a large-scale tree inventory of upland rain forest in the Central Amazon. Acta Amazonica 22: 493-534. - doi: 10.1590/1809-43921992224534

Ranzani G (1980). Identificação e caracterização de alguns solos da Estação Experimental de Silvicultura Tropical do INPA [Identification and characterization of some soils at INPA's Tropical Silviculture Experimental Station]. Acta Amazonica 10: 7-41. [in Portuguese] - doi: 10.1590/ 1809-43921980101007

Rowland L, Hill TC, Stahl C, Siebicke L, Burban B, Zaragoza-Castells J, Ponton S, Bonal D, Meir P, Williams M (2014). Evidence for strong seasonality in the carbon storage and carbon use efficiency of an Amazonian forest. Global Change Biology 20: 979-991. - doi: 10.1111/gcb.12375

Saatchi SS, Houghton RA, Alvalá RCS, Soares JV, Yu Y (2007). Distribution of aboveground live biomass in the Amazon basin. Global Change Biology 13: 816-837. - doi: 10.1111/j.1365-2486.200 7.01323.x

Sharkey TD, Yeh S (2001). Isoprene emission from plants. Annual Review of Plant Biology 52: 407-436. - doi: 10.1146/annurev.arplant.52.1.407 Silva RP, Nakamura S, Azevedo CP, Chambers J, Rocha RD, Pinto AC, Santos JS, Higuchi N (2003). Use of metallic dendrometers for individual diameter growth patterns of trees at Cuieiras river basin. Acta Amazonica 33: 67-84. doi: 10.1590/1809-4392200331084

Slot M, Winter K (2016). The effects of rising temperature on the ecophysiology of tropical forest trees. In: "Tropical Tree Physiology", vol. 6 (Goldstein G, Santiago LS eds). Springer International Publishing, Cham, Germany, pp. 385412. - doi: 10.1007/978-3-319-27422-5_18

Wagner $F$, Rossi $V$, Aubry-Kientz $\bar{M}$, Bonal $D$, Dalitz H, Gliniars R, Stahl C, Trabucco A, Hérault $B$ (2014). Pan-tropical analysis of climate effects on seasonal tree growth. PLoS One 9 (3): e92337. - doi: 10.1371/journal.pone.0092337

Wagner F, Rossi V, Stahl C, Bonal D, Herault B (2012). Water availability is the main climate driver of neotropical tree growth. PLoS One 7 (4): e34074. - doi: 10.1371/journal.pone.0034074 Yang J, Tian H, Pan S, Chen G, Zhang B, Dangal S (2018). Amazon drought and forest response: largely reduced forest photosynthesis but slightly increased canopy greenness during the extreme drought of 2015/2016. Global Change Biology 24: 1919-1934. - doi: 10.1111/gcb.14056

\section{Supplementary Material}

Tab. S1 - Bivariate relationship (Pearson's correlation, $r$ ) between the micrometeorological variables, and between detrended growth rates per species and the climate variables.

Tab. S2 - Repeated measures analysis of variance of the effect of year, month and species on the radial growth rate of the trees.

Tab. S3 - Principal component regression of the relationship between $T_{\mathrm{cc} \text {-mean }}$ and the principal components $z_{1}$ and $z_{3}$.

Tab. S4 - Regression coefficients (Beta, B) obtained by Principal Component Regression (PCR) of the effect of climatic variables on detrended tree growth $\left(T_{\mathrm{CC}}\right)$ of studied species.

Tab. S5 - Mean monthly tree growth ( $\mathrm{mm}$ month $^{-1}$ ) per species during the study period (January 2013 to December 2017).

Tab. S6 - Detrended tree growth data used in PCR analysis.

Tab. S7 - Standardized climate data used in PCR data analysis.

Link: Antezana-Vera_3532@supplo01.pdf 